\title{
PENGGUNAAN MEDIA GAMBAR DALAM KETERAMPILAN MENULIS PUISI DI SEKOLAH DASAR
}

(Studi Multikasus pada Tiga Sekolah Dasar di Kecamatan Wonodadi Blitar)

\section{Tahta Qurotu A'yunina1}

Email: tahtayuyun@gmail.com

\begin{abstract}
The learning process is basically demands the ability of teachers to control students' learning activities. Although not every learning activity, students rely on the presence of the teacher, but there is a causal relationship between teachers teach and students learn. Therefore, one of the responsibilities of teachers in the learning process is to design and implement the learning process in a way that students can achieve the goals that have been set. Creating an effective learning with the involvement of students in order to learn and grow going optimization of basic skills and complex skills in students, not an easy task. This requires another aspect that is not only verbal, but the inclusion of a variety of learning resources used by students with attendance and proper use. Therefore, it is necessary as part of the instructional media learning resources. Media helpful image to equip, maintain, and even improve the quality of ongoing learning, learning outcomes, activities, and student motivation. In the process of learning the presence of media images in poetry writing skills have to be particularly important because in the event that material submitted can deliver media as intermediary. This study focused on describing media images in poetry writing skills.

This study aims to determine (1) the use of the techniques of media images in writing skills poetry in Islamic Elementary School Nurul Jadid, State Islamic Elementary School Kolomayan, and Islamic Elementary School Hashim As'ary Wonodadi Blitar, (2) to know the results of students in the use of media images in writing skills poetry in class V Islamic Elementary School Nurul Jadid, State Islamic Elementary School Kolomayan, and Islamic Elementary School Hashim As'ary Wonodadi Blitar. (3) To find out the constraints encountered in the use of media images in writing skills poetry Islamic Elementary School Nurul Jadid, State Islamic
\end{abstract}

\footnotetext{
${ }^{1}$ Dosen Tetap Fakultas Tarbiyah Sekolah Tinggi Ilmu Syari’ah Faqih Asy'ari
} 
Elementary School Kolomayan, and Islamic Elementary School Hashim As'ary Wonodadi Blitar.

This study used a qualitative descriptive approach to the type of multi-case. The subjects were students of class V Islamic Elementary School Nurul Jadid, State Islamic Elementary School Kolomayan, and Islamic Elementary School Hashim As'ary Wonodadi Blitar. The data source consisted of informants, participants, locations, documentation. Data collection techniques by observation, in-depth interviews, and documentation. Analysis of data using data analysis in the case and cross-case analysis of the data. While checking the validity of the data using focus peers, data triangulation, and triangulation of data sources.

From these results, the authors concluded that (1) the use of technical implementation of media images in writing skills poetry in class V Islamic Elementary School Nurul Jadid, State Islamic Elementary School Kolomayan, and Islamic Elementary School Hashim As'ary. material that is difficult / abstract always use a medium of learning and practice for more simplicity, most media image media, direct objects and works of learners, to form an interesting learning invites students to the library, the school environment, to the outdoors, such as rice paddies, rivers and the ground. Techniques used lectures, media images, but it invites children to observe pictures that were in the school environment. (2) the results of students in the use of media images in writing skills poetry in class V Islamic Elementary School Nurul Jadid, State Islamic Elementary School Kolomayan, and Islamic Elementary School Hashim As'ary. Increase enthusiastic learners, enhance creativity and imagination of students, results of using the media image is very good. Learners' achievements can be increased more than if not using the media. (3) the constraints faced in the use of media images in writing skills poetry Islamic Elementary School Nurul Jadid, State Islamic Elementary School Kolomayan, and Islamic Elementary School Hashim As'ary prepare the medium, time constraints usage, the image must be in accordance with the theme of the picture, no Wi-Fi or internet, elections words (diction).

Keywords: Media Picture, Writing Skills, Poetry 


\section{Pendahuluan}

Pengajaran menulis puisi telah diberikan kepada siswa Sekolah Dasar sebagai langkah awal dari pengenalan karya sastra, sehingga ruang lingkup pengajarannya masih sangat sederhana. Meskipun demikian, pembelajaran menulis puisi memberikan kesempatan pada siswa untuk berkarya seluas-luasnya dan menambah kosa kata baru yang belum pernah digunakan dalam bahasa umum. Tujuan umum pengajaran sastra di sekolah dasar yaitu agar siswa mampu menikmati dan memanfaatkan karya sastra untuk mengembangkan kepribadian, memperluas wawasan kehidupan, serta meningkatkan pengetahuan dan kemampuan berbahasa. ${ }^{2}$ Berdasarkan tujuan tersebut, maka dengan diberikannya pembelajaran menulis puisi di sekolah dasar diharapkan kepekaan perasaan, kejiwaan, pikiran, dan indra siswa dapat lebih terasah dan berkembang.

Dalam rangka memaksimalkan keterampilan peserta didik dalam menulis puisi, diperlukan sebuah media pembelajaran yang tepat. Sehubungan dengan hal tersebut, guru memegang peranan yang paling menentukan. Guru harus memikirkan media apa yang paling tepat untuk diterapkan. Oleh karena itu, guru harus pandai memilih dan menggunakan media secara arif dan bijaksana agar hasilnya nanti dapat memuaskan.

Penelitian ini mengambil lokasi MI Nurul Jadid, MIN Kolomayan dan SDI Hasyim As'ari yang berada di bagian barat kabupaten Blitar. Alasan memilih ketiga lokasi karena sekolah ini termasuk sekolah yang menggunakan media pada saat proses pembelajaran khusunya media gambar pada saat pembelajaran bahasa indonesia. Pembelajaran menulis puisi dengan media gambar juga berdampak positif bagi psikologis peserta didik, pada mulanya peserta didik hanya diam dan tidak mempunyai keberanian untuk berinteraksi, baik dengan guru maupun dengan temannya. Dengan adanya media gambar maka peserta didik semakin antusias dalam psoses pembelajaran berangsung. Faktor yang menentukan keberhasilan tujuan pembelajaran menulis puisi antara lain: kurikulum, peserta didik, media pembelajaran, fasilitas sumber belajar, dan guru. Pembelajaran yang inovatif dan kreatif menuntut penggunaan media pembelajaran yang tepat dan sesuai dengan materi dan tingkat perkembangan peserta didik sehingga peserta didik lebih tertarik dan tumbuh minat untuk memfokuskan perhatiannya selama proses pembelajaran berlangsung.

\footnotetext{
2 Depdiknas, Kurikulum 2004 Bahasa Indonesia untuk Sekolah Dasar dan Madrasah Ibtidaiyah (Jakarta; Depdiknas, 2003), h. 7
} 


\section{Metode Penelitian}

Pendekatan yang digunakan adalah pendekatan kualitatif, yaitu penelitian yang dilakukan untuk menghasilkan data diskriptif baik berupa tulisan maupun lisan serta perilaku dari subyek yang diamati. Bogdan dan Tailor seperti yang dikutip oleh Moleong mendefinisikannya sebagai prosedur penelitian yang menghasilkan data deskriptif berupa kata-kata tertulis atau lisan dari orang-orang dan perilaku yang diamati". ${ }^{3}$ Penelitian yang diambil untuk mendekripsikan data yang berasal dari lembaga yang telah diteliti berupa kata-kata tertulis atau lisan dari orang-orang dan perilaku yang diamati.

Salah satu ciri khas dalam penelitian kualitatif adalah bahwa penelitian berkedudukan sebagai instrumen utama, sedangkan instrumen non manusia bersifat sebagai data pelengkap. Kehadiran peneliti merupakan kunci keberhasilan atau pemahaman terhadap beberapa kasus. Peneliti bertindak sebagai instrumen utama dalam pengumpulan data atau instrumen kunci. ${ }^{4}$ Sesuai dengan jenis penelitian diatas adalah kualitatif, maka cara pengumpulan data dilakukan dengan empat teknik yaitu: wawancara, observasi, catatan lapangan, dokumentasi.

Dalam penelitian ini, analisis data tentang Penggunaan Media Gambar dalam Keterampilan Menulis Puisi pada tiga Sekolah Dasar pada Peserta didik Kelas V, peneliti melakukan penelitian saat kegiatan berlangsung dan setelah pengumpulan data selesai. Pada saat melakukan observasi berbagai kegiatan yang berhubungan dengan kepemimpinan kepala sekolah dalam pemberdayaan tenaga pendidik, serta saat melakukan wawancara kepada semua informan baik kepada sekolah, guru dan semua stakeholder yang terkait dengan keterampilan menulis puisi melalui media gambar di setiap sekolah yang menjadi kasus penelitian, peneliti sudah melakukan analisis terhadap data hasil pengamatan dan wawancara untuk pengembangan lebih lanjut. Kemudian setelah kegiatan penelitian selesai peneliti melakukan analisis secara komprehensif untuk kepentingan pemaparan hasil dan penegasan kesimpulan.

Analisis data lintas kasus dimaksudkan sebagai proses membandingkan temuan-temuan yang diperoleh dari masing-masing kasus, sekaligus sebagai proses memadukan antar kasus. Pada awalnya temuan yang diperoleh SDI Hasyim As'ary disusun kategori dan tema, dianalisis secara induktif konseptual dan dibuat penjelasan naratif yang tersusun menjadi proposisi tertentu yang selanjutnya dikembangkan menjadi teori substansif I. Proposisi-proposisi dan teori substantif I selanjutnya dianalisis dengan cara membandingkan dengan proposisi-proposisi dan teori

\footnotetext{
${ }^{3}$ Lexy J. Moleong, Metodologi Penelitian Kualitatif, (Bandung: Remaja Rosda Karya, 2002), h. 3.

${ }^{4}$ Nasution, Metode Penelitian Naturalik-Kualitatif, (Bandung: Tarsito, 1998), h. 9.
} 
substantif II (temuan dari MI Nurul Jadid Kolomayan). Pembandingan tersebut digunakan untuk menemukan perbedaan karakteristik dari masing-masing kasus sebagai konsepsi teoritik berdasarkan perbedaan-perbedaan. Kedua kasus ini dijadikan temuan kasus I dan II. Selanjutnya temuan yang diperoleh MIN Kolomayan disusun kategori dan tema, dianalisis secara induktif konseptual dan dibuat penjelasan naratif yang tersusun menjadi proposisi tertentu yang selanjutnya dikembangkan menjadi teori substansif III. Pada tahap terakhir dilakukan analisis secara simultan untuk merekonstruks dan menyusun konsepsi tentang persamaan kasus I dan kasus II secara sistematis. Dan pada proses inilah dilakukan analisis lintas kasus antara kasus I, II, dan III dengan teknik yang sama. Analisis akhir ini dimaksudkan untuk menyusun konsepsi sistematis berdasarkan hasil analisis data dan interpretasi teoritik yang bersifat naratif berupa proposisi-proposisi lintas kasus yang selanjutnya dijadikan bahan untuk mengembangkan temuan teori substantif.

Langkah-langkah yang dilakukan dalam analisis lintas kasus ini meliputi: (1) Menggunakan pendekatan induktif konseptualistik yang dilakukan dengan membandingkan dan memadukan temuan konseptual dari masing-masing kasus individu; (2) hasilnya dijadikan dasar untuk menyusun pernyataan konseptual atau proposisi-proposisi lintas kasus, (3) mengevaluasi kesesuaian proposisi dengan fakta yang menjadi acuan; (4) merekonstruksi ulang proposisi-proposisi sesuai dengan fakta dari masing-masing kasus individu; dan (5) mengulangi proses ini sesuai keperluan sampai batas kejenuhan.

\section{Pembahasan}

Dalam proses belajar mengajar kehadiran media mempunyai arti yang sangat cukup penting. Karena dalam kegiatan tersebut ketidakjelasan bahan yang disampaikan dapat dibantu dengan menghadirkan media sebagai perantara. Kerumitan bahan yang akan disampaikan kepada peserta didik dapat disederhanakan dengan bantuan media. Media dapat mewakili kata-kata atau kalimat tertentu. Dengan demikian, peserta didik lebih mudah mencerna bahan dari pada tanpa bantuan media.

Tujuan media pembelajaran sebagai alat bantu pembelajaran adalah sebagai berikut: ${ }^{5}$

a. Agar proses belajar mengajar yang sedang berlangsung dapat berjalan dengan tepat guna dan berdaya guna.

\footnotetext{
${ }^{5}$ Nunuk Suryani, \& Agung Leo. Strategi Belajar Mengajar. (Yogyakarta: Ombak (Anggota IKAPI), 2012), h. 149
} 
b. Untuk mempermudah bagi guru/pendidik dalam menyampaikan informasi materi kepada peserta didik.

c. Untuk mempermudah bagi siswa dalam menyerap atau menerima serta memahami materi yang telah disampaikan oleh guru/pendidik.

d. Untuk dapat mendorong keinginan siswa untuk mengetahui lebih banyak dan mendalam tentang materi atau pesan yang disampaikan oleh guru/pendidik.

Media pembelajaran berfungsi untuk merangsang pembelajaran dengan: ${ }^{6}$

a. Menghadirkan obyek sebenarnya dan obyek yang langka.

b. Membuat duplikasi dari obyek yang sebenarnya.

c. Membuat konsep abstrak ke konsep konkret.

d. Memberi kesamaan persepsi.

e. Mengatasi hambatan waktu, tempat, jumlah, dan jarak.

f. Menyajikan ulang informasi secara konsisten. Memberi suasanan belajar yang tidak tertekan, santai, dan menarik.

Dengan menggunakan media maka materi pelajaran dapat disampaikan dengan baik, jika media yang dibutuhkan tidak tersedia di sekolah maka guru bisa mengusahakan dengan memanfaatkan segala macam benda untuk dijadikan sebagai media tergantung dari kebutuhan.

Hamalik berpendapat bahwa gambar adalah segala sesuatu yang diwujudkan secara visual dalam bentuk dua dimensi sebagai curahan perasaan atau pikiran. ${ }^{7}$

Penggunaan media gambar sebagai media pembelajaran menulis puisi, selain mudah didapatkan juga memudahkan siswa dalam memunculkan ide yang kreatif dalam bentuk puisi. Hal tersebut dikarenakan media gambar mampu menyampaikan pesan atau informasi secara visual sehingga merangsang kreativitas siswa dalam menafsirkan dan mengemukakan sendiri hal-hal yang terkandung di dalamnya. Halhal yang didapat melalui media gambar tersebut selanjutnya dituangkan dalam bentuk rangkaian kata yang kemudian disusun menjadi sebuah puisi.

Gambar yang digunakan sebagai media pembelajaran biasanya memiliki ciriciri berwarna-warni dan kaya dengan variasi. Hal ini dibuat agar dapat menarik perhatian siswa, sehingga perhatian siswa lebih terpusat pada gambar yang ditampilkan oleh guru. Berikut akan dijelaskan kriteria-kriteria pemilihan gambar, antara lain: ${ }^{8}$

\footnotetext{
${ }^{6}$ Asep Herry Hermawan, Pengembangan Kurikulum dan Pembelajaran, (Jakarta, Universitas Terbuka: 2008), h. 11-18

${ }^{7}$ Oemar Hamalik, Media Pendidikan, Cet.VII, (Bandung: PT. Citra Adiyata, 1994), h. 43

${ }^{8}$ Hamalik, Media Pendidikan, h. 85.
} 
1) Sesuai dengan tujuan pembelajaran dan karakteristik siswa. Guru perlu menyesuaikan antara gambar yang digunakan dengan materi pembelajaran. Selain itu, gambar juga berfungsi untuk menampilkan peristiwa atau benda yang tak dapat dihadirkan langsung di kelas. Dengan demikian, guru harus mempertimbangkan karakteristik siswa sehingga dengan adanya gambar, siswa memperoleh pengetahuan dan pengalaman baru.

2) Menstimulir kreativitas pertanyaan, pendapat atau opini. Sesuai dengan tujuan penggunaan media pembelajaran, khususnya media gambar, hendaknya gambar yang dipilih guru dapat memancing siswa untuk bertanya dan mengeluarkan pendapatnya.

3) Keaslian gambar. Gambar yang dipilih hendaknya sesuai dengan aslinya sehingga seakan-akan siswa melihat keadaan atau benda sesungguhnya.

4) Kesederhanaan. Kesederhanaan gambar akan lebih memudahkan siswa dalam menerima informasi yang tersirat pada gambar dan mengandung nilai praktis.

5) Bentuk item. Bentuk gambar yang dipilih masih sederhana. Tidak terlalu mendetail, karena akan mempersulit siswa untuk memahami gambar. Selain itu, kesederhanaan gambar lebih mencirikan karakteristik siswa kelas rendah.

6) Perbuatan. Gambar menunjukkan akivitas yang memberikan tanggapan baik bagi siswa. Sehingga mempengaruhi sikap siswa untuk berbuat baik.

7) Artistik. Meskipun sederhana, gambar hendaknya tetap memiliki nilai seni agar siswa senang mengikuti pembelajaran.

Bagi siswa sangat berharga dalam proses belajarnya sebab memperoleh pengalaman dari kegiatan yang dilakukannya. Siswa merencanakan bagaimana seharusnya sebuah model dapat menggambarkan bagian terpenting, serta melakukan percobaan dengan bahan-bahan yang ada untuk membuat model. Proses perencanaan sebuah model yang terbaik bagi para siswa, pertama-tama adalah mengumpulkan foto-foto, gambar-gambar serta gambaran keseluruhan dari objek asli atau meneliti objek aslinya. Berdasarkan data itu mereka membuat sket model yang akan mereka rencanakan pembuatannya. Penggambarannya itu sering diungkapkan dari tiga sudut pandangan: depan, samping, dan atas. Bagaimanapun, objek bagian depan dan belakang atau samping tidak sama. Oleh karena itu perlu menggambar sket imbuhan 
pandangan dari belakang, membiarkan bagian samping dan mungkin perlu bagian pandangan bawahnya. ${ }^{9}$

a. Obyek Langsung atau benda-benda nyata

Menggunakan benda-benda atau makhluk hidup (real life materias) dalam pengajaran sering kali peling baik, dalam menampilkan benda-benda nyata tentang ukuran, suara, gerak-gerik, permukaan, bobot-badan, bau serta manfaatnya. Peran siswa akan lebih banyak belajar misalnya tentang ayam hutan yang dikandang di kelas untuk dipelajari, dibandingkan sekadar melihatnya di gambar. Para siswa akan lebih terkesan dengan peragaan menembak tepat yang didemonstrasikan oleh roman ditektif. Mereka akan belajar lebih banyak tentang binatang serangga yang dikumpulkan dari hasil perjalanan karya wisata, dibandingkan dengan melihatnya di film strip mengenai kehidupan binatang tersebut. ${ }^{10}$

Dalam mempergunakan benda-benda nyats untuk tujuan pengajaran, guru hendaknya mempertimbangkan hal-hal berikut: ${ }^{11}$

1) Benda-benda atau makhluk hidup apakah yang mungkin dimanfaatkan di kelas secara efesien.

2) Bagaimana caranya agar semua benda itu bersesuaian sekali terhadap pola belajar siswa.

3) Dari mana sumbernya untuk memperoleh benda-benda itu.

Benda-benda nyata itu banyak macamnya, mulai dari benda atau makhluki hidup seperti binatang dan tumbuh-tumbuhan, juga termasuk benda-benda mati misalnya batuan, air, tanah, dan lain-lain.

a. Untuk membentuk pembelajaran yang menarik mengajak peserta didik ke perpustaakaan, lingkungan sekolah, kealam terbuka, seperti sawah, sungai dan lapangan.

b. Teknik dan Langkah-langkah Penggunaan Media Gambar

Teknik yang digunakan ceramah, media gambar, selain itu mengajak anak untuk mengamati gambar yang berada di lingkungan sekolah misalnya di ruang perpustakaan, dan laboratorium. Gambar-gambar dapat digunakan untuk suatu maksud lain dalam hubungan suatu pelajaran, memberi pengalaman dasar, menjelaskan dan sebagainya. Guru harus merencanakan penggunaan media gambar untuk menghindari kesukaran dan untuk

\footnotetext{
9 Nana Sudjana, Media Pengajaran, (Bandung: Sinar Baru, 1991), h. 196.

${ }^{10}$ Ibid, h. 196.

${ }^{11}$ Ibid.
} 
penggunaan secara efektif. Guru juga harus mengetahui gambar yang akan digunakan sehingga dapat dipandang secara baik.

Agar supaya pengajar mempunyai arti dan efektif bagi peserta didik mempertahankan informasi dari guru maka sebaiknya: ${ }^{12}$

a. Guru wajib menambah bahan-bahan lain selain gambar untuk memotivasi peserta didik.

b. Gambar harus dibuat oleh guru sedapat mungkin yang berlainan dengan yang ada dibuku teks wajib belajar.

c. Guru harus menyadari bahwa ada kalanya gambar sederhana tidak diperlukan.

Dalam pembelajaran dengan menggunakan media dapat dikatakan berhasil jika peserta didik mendapatkan nilai atau hasil akhir yang baik. ${ }^{13}$ Dan dikatakan belum berhasil jika nilai atau hasil akhir dari proses tersebut jelek. Tetapi dengan menggunakan media pembelajaran terutama media gambar, guru mendapatkan nilai yang bagus karena telah menggunakan media pembelajaran, maka pelajaran akan mudah diterima oleh peserta didik.

Ide-ide itu muncul ketika peserta didik sudah diberikan media gambar. Proses pembelajaran dengan media gambar menuntut seorang pendidik untuk bisa kreatif dalam menyajikan. Misalnya penggunaan media dengan cara berbagai jenis permainan, dikombinasikan dengan simbol, angka, pelafalan latin dan pemberian penghargaan kepada peserta didik yang berprestasi. Kombinasi penggunaan media gambar dengan poster, balok imajinasi, bisa menagajak anak mengenal berbagai bentuk, ciri-ciri, manfaat, dan sebagainya. Dengan cara ini diharapkan peserta didik mampu mendeteksi, mengelompokkan, menganalisa, sintesis, dan pemecahan masalah. ${ }^{14}$

Evaluasi pada dasarnya adalah memberikan pertimbangan atau harga nilai berdasarkan kriteria tertentu, untuk mendapatkan evaluasi yang meyakinkan dan objek dimulai dari informasi-informasi kuantitatif dan kualitatif. Instrumennya (alatnya) harus cukup sahih, kukuh, praktis, dan jujur. Data yang dikumpulkan dari pengadministrasian instrument itu hendaklah diolah dengan tepat dan digambarkan pemakaiannya. ${ }^{15}$

12 Arista Ika Widiyanti, Penggunaan Media Gambar Seri untuk Meningkatkan Kemampuan Menulis Karangan Narasi, (Tulungagung: IAIN Tulungagung, 2014), h. 21-23

${ }^{13}$ Wina Sanjaya, Perencanaan dan Desain System Pembelajaran, (Jakarta: Kencana Prenada Media Group, 2009), h. 211.

${ }^{14}$ Deny Setiawan, Komputer dan Media Pembelajaran, (Jakarta: Universitas Terbuka, 2008), h. 44

15 Syaiful Bahri Dhamarah, Guru dan Anak Didik dalam Interraksi Edukatif, (Jakarta: Rineka Cipta, 2005), h. 245 
Sementara Luxemburg menyebutkan bahwa "puisi adalah teks-teks monolog yang isinya merupakan sebuah alur". ${ }^{16}$

1) Bentuk dan struktur fisik puisi

Bentuk dan struktur fisik puisi meliputi: perwajahan puisi atau tipografi, diksi, pengimajian, kata konkret, majas atau bahasa figuratif dan verifikasi. Bentuk-bentuk ini akan dijelaskan berikut in: ${ }^{17}$

a) Perwajahan puisi (tipografi)

Dimulai dengan huruf besar dan diakhiri dengan titik (.). Kumpulan pernyataan dalam puisi tidak membentuk paragraf, tetapi membentuk bait. Sebuah bait dalam suatu puisi mengandung satu pokok pikiran. Pengaturan dalam bait-bait ini sudah berkurang atau sama sekali tidak ada pada puisi modern atau puisi kontemporer. Bahkan, puisi kontemporer tipografinya bisa membentuk suatu gambar atau biasa disebut puisi konkret. Pengaturan baris dalam puisi sangat berpengaruh terhadap pemaknaan puisi karena menentukan kesatuan makna dan memunculkan ketaksaan makna (ambiguitas). Perwajahan puisi juga dapat mencerminkan maksud dan jiwa pengarangnya.

b) Diksi

Diksi adalah pemilihan kata-kata yang dilakukan oleh penyair dalam puisinya. Karena puisi adalah karya sastra yang sedikit menggunakan kata-kata untuk mengungkapkan hal, kata-katanya harus dipilih secermat mungkin. Pemilihan kata-kata dalam puisi berhubungan erat dengan makna, keselarasan bunyi dan urutan kata. Selain itu pemilihan kata berhubungan erat dengan latar belakang penyair. Semakin luas wawasan penyair, semakin kaya dan berbobot kata-kata yang digunakan.

c) Pengimajian

Pengimajian adalah kata atau kelompok kata yang dapat mengungkapkan pengalaman indrawi, seperti penglihatan, pendengara, dan perasaan. Imaji dibagi menjadi tiga yaitu imaji suara (auditif), imaji penglihatan (visual), dan imaji raba atau sentuh (imaji taktil). Imaji dapat mengakibatkan pembaca seakan-akan melihat, mendengar, dan merasakan seperti yang dialami oleh penyair. Imaji berhubungan erat dengan kata konkret.

\footnotetext{
${ }^{16}$ Jan Van Luxemburg, Mieke Bald dan Willem G. Weststeijn, Pengantar Ilmu Sastra, Terjemahan Dick Hartoko, (Jakarta: Gramedia, 1984), h. 175

${ }^{17}$ Siswanto, Pengantar Teori, h. 108-119.
} 
d) Kata konkret

Kata konkret erat hubungannya dengan imaji. Kata konkret adalah kata-kata yang dapat ditangkap dengan indra. Dengan kata konkret kemungkinan imaji akan muncul.

e) Bahasa figuratif (majas)

Bahasa figuratif merupakan retorika sastra yang sangat dominan. Bahasa figuratif merupakan cara pengarang dalam memanfaatkan bahasa untuk memperoleh efek estetis dengan pengungkapan gagasan secara kias yang menyaran pada makna literal (literal meaning). Bentuk bahasa figuratif yang banyak dimanfaatkan oleh para sastrawan adalah majas, idiom, dan peribahasa. Ketiganya dipandang sebagai sarana sastra yang representatif dalam mendukung gagasan pengarang.

f) Verifikasi (rima, ritme, dan metrum)

Verifikasi dalam puisi terdiri atas rima, ritme, dan metrum. Terdapat perbedaan konsep antara rima dan sajak. Sajak adalah persamaan bunyi pada akhir baris puisi, sedangkan rima adalah persamaan bunyi pada puisi baik di awal, tengah, maupun akhir baris puisi. Ada yang menyamakan antara ritme dengan metrum. Ritme adalah tinggi-rendah, panjangpendek, keras-lemahnya bunyi. Ritme sangat menonjol bila puisi dibacakan.

2) Struktur Batin Puisi

Menurut I. A. Richards dalam Wahyudi struktur batin puisi terdiri empat unsur yaitu: tema, makna (sense), rasa (feeling), nada (tone) dan amanat; tujuan; maksud (intention). Masing-masing struktur batin ini akan dijelaskan sebagai berikut: ${ }^{18}$

a) Tema adalah gagasan pokok yang ingin disampaikan oleh pengarang.

b) Rasa dalam puisi merupakan sikap penyair terhadap pokok permasalahan yang terdapat dalam puisinya. Pengungkapan tema dan rasa berkaiatan erat dengan latar belakang sosial dan psikologi penyair. Ketepatan penyair dalam menyikapi suatu masalah tidak bergantung pada kemampuan penyair memilih kata-kata, rima, gaya bahasa, dan bentuk puisi saja, tetapi lebih banyak bergantung kepada wawasan, pengetahuan, pengalaman, dan kepribadian yang terbentuk oleh latar belakang sosiologis dan psikologisnya.

\footnotetext{
${ }^{18} \mathrm{Ibid}, 124-125$.
} 
c) Nada dalam puisi adalah sikap penyair terhadap pembacanya. Nada juga berhubungan dengan tema dan rasa. Ada penyair yang dalam menyampaikan tema dengan nada menggurui, mendikte, bekerja sama dengan pembaca untuk memecahkan masalah, menyerahkan masalah begitu saja kepada pembaca, dengan nada sombong, menganggap bodoh rendah pembaca dan sebagainya.

3) Amanat atau Tujuan

Secara sadar atau tidak, tujuan selalu ada dalam diri penyair untuk menciptakan puisi. Tujuan dapat dicari sebelum puisi diciptakan atau dapat ditemui dalam puisinya. ${ }^{19}$

Setiap selesai akan dilakukan refleksi menanyakan kepada peserta didik tentang kegiatan pembelajaran pada hari ini. Kemudian penilaiannya berdasarkan gambar yang telah di tulis peserta didik yang disesuaikan dengan rubrik penilaian. Setelah pembelajaran dilakukan refleksi terhadap media yang telah digunakan, sehingga bisa dimanfaatkan kembali media yang efektif dan efisien.

Secara umum media memiliki beberapa manfaat, antara lain: ${ }^{20}$ (a) Memperjelas pesan agar tidak terlalu verbalitas. (b) Mengatasi keterbatasan ruang, waktu tenaga dan daya indra, seperti misalnya objek benda yang terlalu besar, bisa diganti dengan gambar, film bingkai, film atau model. (c) Menimbulkan gairah belajar, interaksi lebih langsung antara murid dengan sumber belajar. (d) Memungkinkan anak belajar mandiri sesuai dengan bakat dan kemampuan visual, auditori dan kinestetiknya. (e) Memberi rangsangan yang sama, mempersamakan pengalaman dan menimbulkan persepsi yang sama. Selain itu manfaat yang bisa melatih menemukan kata-kata, gambarnya mudah dipahami, karena gambarnya bisa dilihat langsung, dan bisa memperoleh pengalaman.

Kenyataan saat ini antusias peserta didik meningkat ketika guru menggunakan media. Mereka memerlukan alat-alat yang membantu lancarnya belajar peserta didik dalam jumlah yang besar pula. Media yang digunakan seperti media gambar, media audiovisual, dan media langsung.

\footnotetext{
${ }^{19}$ Ibid, h. 125

${ }^{20}$ Cepi Riyana, Media Pembelajaran, (Jakarta: Dirjen Pendidikan Islam Kementerian Agama Republik Indonesia, 2012), h. 13-14.
} 
Problem atau kendala adalah sebagai permasalahan dalam menghadapi proses pembelajaran. Dengan menggunakan media pembelajaran permasalahan ataupun kendala pasti ada, dan dihadapi oleh guru. ${ }^{21}$

Dalam proses pembelajaran media merupakan bagian terpenting dlari sebuah kegiatan pendidikan. Proses pembelajaran adalah suatu upaya untuk mencapai tujuan pendidikan.

Berdasarkan kendala penggunaan media gambar dalam keterampilan menulis puisi kelas V di SDI Hasyim As'ary, MI Nurul Jadid, dan MIN Kolomayan Wonodadi Blitar bahwa:

a. mempersiapkan medianya,

b. keterbatasan waktu penggunaannya,

c. gambar harus sesuai dengan tema gambar,

d. tidak adanya wifi atau internet

Internet merupakan kependekan dari international network yang merupakan jaringan yang dapat menghubungkan semua server yang ada di seluruh dunia. Untuk menjadikan kom puter dapat berhubungan melalui jaringan www, baik pribadi maupun organisasi, diperlukan beberapa komponen sehingga pemilik komputer dapat berinteraksi antara server di seluruh dunia untuk memperoleh data. ${ }^{22}$

e. pemilihan kata-kata (Diksi)

Diksi adalah pemilihan kata yang dilakukan oleh penyair untuk mengekspresikan gagasan dan perasaan-perasaan yang bergejolak dan menggejala dalam dirinya. Untuk dapat memilih kata dengan baik diperlukan penguasaan bahasa. Tanpa menguasai bahasa dengan baik maka sangat sulit bagi penyair untuk memilih kata dengan cermat. Dengan demikian syarat utama dalam diksi adalah penguasaan bahasa yang baik. Diksi atau pilihan kata digunakan penyair untuk mengungkapkan maksud atau ide dan efek puitis yang ingin dicapai. Diksi juga dapat mendukung latar dan suasana yang ingin diekspresikan. ${ }^{23}$

Peranan diksi dalam puisi sangat penting karena kata-kata adalah segalagalanya dalam puisi. Kata-kata tidak sekadar berperan sebagai sarana yang

${ }^{21}$ Hamzah B. Uno, Model Pembelajaran Menciptakan Proses Belajar Mengajar yang Kreatif dan Efektif, (Jakarta: Bumi Aksara, 2012), h. 1.

${ }^{22}$ Denny Setiwan, Komputer dan Media Pembelajaran, (Jakarta: Universitas Terbuka, 2011), h.8-19

${ }^{23}$ Suminto A. Sayuti, Berkenalan dengan Puisi. (Yogyakarta: Gama Media, 2002), h. 143. 
menghubungkan pembaca dengan gagasan penyair, seperti peran kata dalam bahasa sehari-hari dan prosa umumnya.

Bagi siswa sangat berharga dalam proses belajarnya sebab memperoleh pengalaman dari kegiatan yang dilakukannya. Siswa merencanakan bagaimana seharusnya sebuah model dapat menggambarkan bagian terpenting, serta melakukan percobaan dengan bahan-bahan yang ada untuk membuat model. Proses perencanaan sebuah model yang terbaik bagi para siswa, pertama-tama adalah mengumpulkan foto-foto, gambar-gambar serta gambaran keseluruhan dari objek asli atau meneliti objek aslinya. Berdasarkan data itu mereka membuat sket model yang akan mereka rencanakan pembuatannya. Penggambarannya itu sering diungkapkan dari tiga sudut pandangan: depan, samping, dan atas. Bagaimanapun, objek bagian depan dan belakang atau samping tidak sama. Oleh karena itu perlu menggambar sket imbuhan pandangan dari belakang, membiarkan bagian samping dan mungkin perlu bagian pandangan bawahnya. ${ }^{24}$

\section{Kesimpulan}

Berdasarkan hasil temuan dan pembahasan penelitian tentang Penggunaan Media Gambar dalam Keterampilan Menulis Puisi di sekolah dasar. (studi multikasus pada sekolah dasar di kecamatan wonodadi blitar) maka kesimpulan penelitian ini adalah sebagai berikut:

a. Teknik Penggunaan Media Gambar dalam Keterampilan Menulis Puisi Kelas V.

1) Menyampaikan materi yang sulit/abstrak selalu menggunakan media pembelajaran dan praktik karena lebih mempermudah.

2) Media yang biasa digunakan di SDI Hasyim As'ary adalah berupa media gambar, dan obyek langsung. Di MI Nurul jadid media yang biasa digunakan memakai media langsung dan media gambar. Sedangkan di MIN Kolomayan media yang biasa digunakan gambar dan hasil karya peserta didik.

3) Untuk membentuk pembelajaran yang menarik di SDI Hasyim As'ary adalah mengajak peserta didik ke perpustaakaan, lingkungan sekolah, kealam terbuka, seperti sawah, sungai dan lapangan. Di MI Nurul jadid mengajak peserta didik ke sekitar area sekolah sehingga peserta didik bisa menemukan pengalaman baru, karena masing-masing peserta didik mempunyai gaya belajar yang berbeda. Sedangkan di MIN Kolomayan mengajaknya kealam terbuka, khusunya di lingkungan sekitar sekolah saja seperti sawah, sungai dan lapangan.

\footnotetext{
${ }^{24}$ Nana Sudjana, Media Pengajaran, (Bandung: Sinar Baru, 1991), h. 196.
} 
4) Teknik dan langkah-langkah penggunaan media gambar di SDI Hasyim As'ary adalah digunakan ceramah, media gambar, selain itu mengajak anak untuk mengamati gambar yang berada di lingkungan sekolah misalnya di ruang perpustakaan, dan laboratorium. Di MI Nurul jadid gambar diberikan kepada masing-masing peserta didik, gambar harus menarik, gambar harus sesuai dengan karakteristik siswa, kemudian peserta didik mengerjakan dengan gaya yang sebebas-bebasnya, agar hasilnya bisa efektif dan efisien. Sedangkan di MIN Kolomayan mencari gambar yang sesuai dengan tema kemudian memberikan gambar secara merata keseluruh peserta didik.

b. Hasil Penggunaan Media Gambar dalam Keterampilan Menulis Puisi Kelas V

1) Meningkatkan antusias peserta didik, antusiasnya dalam hal menulis puisi saja, tetapi dalam hal membaca tidak semua siswa bisa.

2) Meningkatkan kreatifitas dan imajinasi peserta didik.

3) Evaluasi penggunaan media gambar di SDI Hasyim As'ary adalah berdasarkan gambar yang telah di tulis peserta didik, kemudian disesuaikan dengan rubrik penilaian. Di MI Nurul jadid puisi dikoreksi mana yang sesuai dengan bentuk dan struktur puisi yang disesuaikan dengan rubrik penilaian. Seperti diksi, kesesuaian tema, ejaan. Sedangkan di MIN Kolomayan puisi berdasarkan gambar yang telah di tulis peserta didik, kesesuaian dengan tema, judul, ejaan, diksinya.

4) Hasil dari menggunakan media gambar sangat baik. Prestasi peserta didik lebih bisa meningkat dibandingkan jika tidak menggunakan media

5) Manfaat menulis puisi menggunakan media gambar

c. Kendala-kendala dari Penggunaan Media Gambar dalam Keterampilan Menulis Puisi Kelas V

1) Kendala-kendala penggunaan media gambar dalam keterampilan menulis puisi di SDI Hasyim As'ary adalah keterbatasan waktu, tidak adanya wifi, dan pemilihan kata-kata. Di MI Nurul jadid keterbatasan waktu yang digunakan untuk mempersiapkan medianya. Saran untuk membuat media gambar tersebut, media gambar hanya terbatas pada masing-masing peserta didik. Sedangkan di MIN Kolomayan keterbatasan waktu, gambar harus sesuai dengan tema gambar, dan pemilihan kata-kata.

Cara mengatasi peserta didik yang ramai SDI Hasyim As'ary mengganti media yang tadinya dipersiapkan oleh guru, kemudian diganti dengan gambar dari peserta didik sendiri, selanjutnya gambar yang telah jadi dikembangkannya dengan membuat puisi. Di MI Nurul jadid mengganti gaya belajar, yang tadinya 
belajar berada di dalam kelas maka mengajak peserta didik untuk keluar kelas, agar peserta didik bisa mendapatkan gaya belajar yang berbeda-beda sesuai dengan kemauannya. Sedangkan di MIN Kolomayan mengganti dengan media hasil karya peserta didik sendiri

\section{Daftar Pustaka}

Arista, Widiyanti Ika. 2014. Penggunaan Media Gambar Seri untuk Meningkatkan Kemampuan Menulis Karangan Narasi, Tulungagung: IAIN Tulungagung.

Asep, Herry Hermawan, 2008. Pengembangan Kurikulum dan Pembelajaran, Jakarta, Universitas Terbuka.

Depdiknas. 2003. Kurikulum 2004 Bahasa Indonesia untuk Sekolah Dasar dan Madrasah Ibtidaiyah, Jakarta; Depdiknas.

Djamarah, Syaiful Bahri. 2005. Guru dan Anak Didik dalam Interraksi Edukatif, Jakarta: Rineka Cipta.

Hamalik, Oemar.1994 Media Pendidikan, Cet.VII, Bandung: PT. Citra Adiyata.

Luxemburg, Jan Van. 1984. Mieke Bald dan Willem G. Weststeijn, Pengantar Ilmu Sastra, Terjemahan Dick Hartoko, Jakarta: Gramedia, 1984.

Moleong, Lexy J. 2002. Metodologi Penelitian Kualitatif, Bandung: Remaja Rosda Karya.

Nasution. 1998. Metode Penelitian Naturalik-Kualitatif. Bandung: Tarsito.

Riyana, Cepi. 2012. Media Pembelajaran, Jakarta: Dirjen Pendidikan Islam Kementerian Agama Republik Indonesia.

Sanjaya, Wina. 2009. Perencanaan dan Desain System Pembelajaran, Jakarta: Kencana Prenada Media Group.

Setiawan, Deny. 2008. Komputer dan Media Pembelajaran, (Jakarta: Universitas Terbuka.

Setiwan, Denny. 2011. Komputer dan Media Pembelajaran, Jakarta: Universitas Terbuka.

Sudjana, Nana. 1991. Media Pengajaran, Bandung: Sinar Baru.

Suminto A. Sayuti, 2002. Berkenalan dengan Puisi. .Yogyakarta: Gama Media.

Suryani, Nunuk. \& Agung Leo. 2012. Strategi Belajar Mengajar. Yogyakarta: Ombak.

Uno, Hamzah B. 2012. Model Pembelajaran Menciptakan Proses Belajar Mengajar yang Kreatif dan Efektif, Jakarta: Bumi Aksara. 